\title{
Technological Capabilities of Brazilian Shipbuilding Suppliers
}

\author{
Marcos André Mendes Primol, Frank DuBois²
}

\begin{abstract}
Technological capabilities (TC) play a key role in the competitiveness of firms in industrial sectors. Suppliers in emerging economies often acquire technological capabilities by operating and mastering technologies developed by others and then leveraging this learning to develop indigenous technologies. By reviewing research on firm specific technological capabilities, the development of global value chains and industrial clusters in emerging markets we discuss local suppliers' insertion and upgrading in the supply chains of new large industrial enterprises. Using the Brazilian shipbuilding industry as context, we investigate and develop propositions related to the ability of local suppliers to develop technological capabilities that permit eventual insertion into the local supply chain. This research has applications for managers and policy makers from other emerging market countries seeking to increase local sourcing through development of local suppliers.
\end{abstract}

Keywords: Technological capabilities; emerging markets; local sourcing; value chains; clusters; shipbuilding industry.

'Professor Business Administration, Federal University of Pernambuco (UFPE), Recife, PE, Brazil. Phone: 55-8I -2 I268370; E-mail: marcos. primo@ufpe.br.

${ }^{2}$ Professor International Studies, Kogod School of Business Administration, American University, Washington D.C., USA. Phone: I-202885-1967; E-mail: fdubois@american.edu.

ISSN: 07 I8-2724. (http://www.jotmi.org)

Journal of Technology Management \& Innovation (C) Universidad Alberto Hurtado, Facultad de Economía y Negocios. 


\section{Introduction}

Emerging markets, especially those enjoying robust economic activity and an economic policy orientation towards indigenous commercial growth, have often embarked on development projects focused on the creation of high profile national "champions" in specific industrial sectors. These projects are often oriented towards the creation or reinvigoration of large industrial enterprises that will have significant impacts in terms of job creation, economic growth and the attendant spillover benefits into local economic activity. A major challenge confronting these projects is the need to develop a local supply chain infrastructure that will amplify economic impacts to the greatest number of local firms. At issue is the balance between global and local sourcing, especially in situations when the local government is interested in maximizing economic benefits locally (Jin, 2004). In the absence of local sourcing opportunities, organizations may be forced into a situation where they are required to make investments in capital equipment and labor resources to develop internal supply sources.

Likewise, global sourcing strategies, while potentially offering cost and quality advantages, may not allow the same degree of agility and flexibility in supply chain strategy as local sourcing (Kotabe, 1992; Markham and McCart, 1995; $\mathrm{Kim}$ and Takeda, 1995). Jin (2004), for example, argues that local sourcing may bring competitive advantages under conditions of demand uncertainty or when the enterprise has developed long-term relationships with local suppliers. Local suppliers may reduce logistics risks, shorten lead times in the supply chain, provide delivery flexibility and allow firms to achieve local content minimums that are often mandated by local governments (Sturgeon, Biesebroeck and Gereffi, 2008). It is this last objective that is salient to the development of the shipbuilding industry in Brazil'.

Despite strong interest in developing alternative sourcing options, enterprises in emerging markets often face difficulties in finding qualified local suppliers. Local firms often are not in compliance with international standards for products, processes (quality and environment), and labor skills. Inability to meet these standards is an indication of limitations with regard to the technological capabilities of the local firms. Limitations that will impair the extent of supplier participation in the supply chain (at least at the first tier). As a result, lead firms will develop relationships with global supply sources or will vertically integrate processes to manufacture

'For the purposes of this paper we do not distinguish between "home grown" local suppliers or suppliers that are foreign subsidiaries of multinational enterprises. Either type of supplier serves the needs of national political institutions in terms of improving local content measures. products that might normally be outsourced from other companies. Generally speaking, firm-specific technological capabilities are defined as technological developments in the firm's products and services, procedures, processes, equipment, installation, etc., and especially the technological knowledge of the firm workforce (Figueiredo, 200I, 2007). Technological capabilities (TC) of suppliers in emerging markets are defined in terms of a firm's abilities in applying technologies as new technologies appear or extant technologies evolve. Lall (2000) argues that in contrast to suppliers in developed countries, becoming a competitive supplier in an emerging economy does not typically require the same level of innovative effort in developing frontier technologies. First tier suppliers in emerging markets are often on the receiving end of a technology transfer initiative on the part of the lead firm and will adapt imported technology to meet the needs of this buyer(s). At issue is the extent to which the downstream buyer plays a role in brokering the transfer.

An examination of the TC of suppliers in emerging markets gives rise to some interesting research questions. The first is related to the extent that TC impacts the ability of local suppliers to be part of the lead firm's supply chain. An important question is not if, but, what TC related variables matter for local firm insertion into the enterprise supply chain? With the entry of local suppliers into the supply chain, the process that these firms follow in upgrading into higher levels of TC is an important research issue. The presence of a local supplier network will affect sourcing decisions, and consequently, local supplier insertion and upgrading. In addition, the collective efficiency of firms in an industrial cluster and the local innovation system will favor local sourcing initiatives (Schmitz, 1995).

From the aforementioned research streams, we explore possibilities for supplier insertion and upgrading in new industrial enterprise supply chains in emerging countries. With a focus on the Brazilian shipbuilding industry, we discuss propositions about variables related to the technological capability of local suppliers and their success in becoming part of the shipyards' supply chains.

\section{Technological Capabilities in the Shipbuilding Industry}

Ship construction requires significant technological sophistication in production, design and project management (Sohn, Chang and Song, 2010). Ships are considered special projects and are built in small lot sizes, rather than built to stock using traditional assembly line techniques. Technological complexity can vary extensively in the shipbuilding industry. At one extreme are relatively simple bulk commodity carriers such as oil tankers and containerships which are essentially large floating steel boxes. At the other extreme are military

ISSN: 07 I8-2724. (http://www.jotmi.org)

Journal of Technology Management \& Innovation (C) Universidad Alberto Hurtado, Facultad de Economía y Negocios. 
ships such as aircraft carriers and submarines, or commercial vessels like LNG carriers, oil drilling platforms and drill ships, which are technologically dense with large engines and numerous sophisticated high-technology components (Birkler et al., 2005). Despite differences between the two types, there are many similarities with regard to production outsourcing since shipyards concentrate on steel fabrication while using outside suppliers to provide many of the other components ${ }^{2}$. For commercial ships such as oil tankers, the construction of which is characterized by very small profit margins, shipyards rely more on standardized inputs and purchase agreements are generally utilized to get supplier support for different shipbuilding activities. Within the context of Brazilian shipbuilding there was a significant effort to upgrade and modernize an industry that had once been globally competitive.

In the late 1970's the Brazilian shipbuilding industry was the second largest in the world. It directly employed 40,000 workers with an additional 100,000 indirect jobs supporting the industry (Cho and Porter, 1986). The debt crisis in the 1980s led to limitations on capital availability leading buyers to redirect orders to upstart firms in Japan, Singapore, South Korea and later China, who were able to offer lower costs and better schedule reliability (Worldyards, 2009; Fairplay, 2009). By the late 1990s the industry had all but disappeared, shipyards closed, unfinished projects were abandoned on the ways and perhaps a total of 1000 jobs remained (Amorim et al., 1995; Pasin, 2002; Blount, 2009). Circumstances changed in the late 1990s with the discovery of significant oil reserves in the Campos basin off the coast of the state of Rio de Janeiro. The Brazilian government auctioned off exploration blocks and through the initiatives of the partially state owned oil company Petrobras, along with other firms in the global oil industry, there were multiple discoveries of deep water oil reserves. In the early 2000s discoveries in the "pre-salt" area off the Northeast coast led to anticipation that Brazil would become a major exporter of oil as these reserves were developed to their full commercial potential. Potential oil deposits are estimated to rival those of Kuwait and Russia (Blount, 2009).

In 200I Petrobras, through its transport and logistics subsidiary Transpetro, launched the Fleet Modernization Program (PROMEF) to support the growth in offshore oil exploration and drilling. Through PROMEF, Transpetro has undertaken an ambitious effort to reinvigorate the Brazilian shipbuild-

${ }^{2}$ Bernardes and Oliveira (2003) document a similar arrangement in the production process of the Brazil based commercial aircraft producer Embraer. Embraer, as lead firm, is primarily responsible for local fabrication of the fuselage and relies heavily on the supply of high value outsourced components (engines, avionics, landing gear) from global and local suppliers. ing industry through local manufacture of tankers, drilling platforms and support vessels. The Brazilian government supported these initiatives with the creation of a Merchant Marine Fund (MMF) financed through a tax on imports. Shipyards are able to access low cost capital through the MMF but must, in an effort to assure that as much of the benefits of this funding source accrues to the local economy must also comply with a local content index determined by Transpetro.

Brazilian shipyards face the typical problems of new large industrial enterprises in emerging economies that are mandated to become "national champions." Local sourcing may not only be required by local content rules but may also serve as a mechanism to reduce the risks associated with delivery delays and the lack of on-site assistance by global suppliers. However, local suppliers may have limited technological capabilities to comply with the enterprise demands related to product and production processes. Those suppliers may not even be located in organized clusters in order benefit from externalities in developing local firm technological capabilities.

Technological capabilities refer to a firm's ability to make effective use of technological knowledge in Engineering/production, and innovation in order to be competitive in price and quality (Kim, 2000). From this perspective, in the shipbuilding industry, there is a need to develop capabilities related to ship and shipyard design, standard ship construction procedures, and operations management of the shipbuilding process (production capabilities) (Koenig, 2002). In addition, there is the need to develop capabilities to incorporate new production processes and product-related technologies (innovation capabilities) into subsequent designs ${ }^{3}$.

As stated in an earlier section, firms in emerging markets normally follow a different technological trajectory from that seen in developed countries (Figueiredo, 200I). Technological knowledge may be acquired by initially searching for, operating, and mastering technology developed by others, rather than developing technology locally. Technology trajectories typically follow a sequence of initially developing operational or production capabilities; design, engineering and associated management capabilities; and eventually, developing local R\&D capabilities (Bell, 2007).

In contrast to the military and cruise ship markets, the commercial shipbuilding industry is characterized by a low cost focus and medium technological sophistication (Sohn, Chong, and Song, 2010; Birkler et al., 2004). While barriers to entry are normally relatively low in comparison to other

${ }^{3}$ See for example Cho and Porter (1986) and Andritsos and PerezPrat (2000). 
industries, the need for construction and operational quality certification requirements in commercial shipping is a significant constraint on firm entry. Because of the greater level of standardization in the final product, commercial shipyards normally concentrate construction efforts on the engineering design and assembly of outsourced parts and components rather than internal manufacture. For the shipyard, the key tasks involve assembly of a hull structure and integration of outsourced components (engine and propulsion systems, navigation systems, etc) into an industry standards compliant and seaworthy product (Koenig, 2002).

In comparison to traditional shipbuilding practice, modern shipyards have adopted more sophisticated and efficient construction practices to keep costs low. A typical ship is composed of "blocks" that are assembled separately and then joined at a later stage in the production process to create the final product. Building a ship in this sort of modular format permits more efficient installation of the various components and simultaneous construction of sections of the ship that would not have been possible using traditional techniques. For example, blocks at the stern of the ship which house more complicated components can be constructed independently of other sections of the ship. This permits propulsion systems, navigation controls, crew quarters, pipes, ballast equipment and ancillary machinery to be installed earlier in the production process. In addition, sandblasting and painting of corrosion susceptible surfaces is can be done prior to assembly into the final hull configuration (Hellström, 2005). Not unlike trends in other manufacturing industries, outsourcing of the manufacture of parts, components and subassemblies has been a natural decision for lowering shipyards' costs while keeping quality standards high (Womack and Jones, 1996; Koenig, Narita and Baba, 2002).

Sourcing alternatives for high value items such as large vessel engines are constrained as a result of few qualified suppliers in the industry. Global sales volumes for these items are low in comparison to other components that find applications in multiple vessel platforms. Investment in production systems for the manufacture of engine and propulsion units is high thereby creating insurmountable entry barriers for all but the largest global suppliers. Uncertainty about future orders also creates entry barriers for new entrants, especially local suppliers. In that context, achieving a globally competitive cost in supplying high value added parts is prohibitive for local suppliers, especially those that do not have the scale economies to develop a global market. As such, local suppliers may develop skills in aggregating, integrating and packaging components sourced from global suppliers. Value is derived not only from the components themselves but from the efforts that the supplier makes in integrating components from different suppliers into a functional module.
In addition to cost competitiveness, technology is important success factor in the shipbuilding industry. Technological sophistication is critical for building complex vessel types such as luxury cruise ships, drilling platforms and military vessels that require specialized know-how and advanced knowledge in vessel design and construction (Andritsos and Perez-Prat, 2000; Birkler et al., 2004). Production competence for more complex vessels (especially military) requires a level of precision in terms of assembly quality similar to that required in the aeronautics industry (Sohn, Chang and Song, 2010). While vessel complexity with respect to oil tankers and container ships is lower, the need for construction process certification to acquire insurance coverage (especially in the case of oil tankers) requires builders to maintain an aggressive posture with regard to technological sophistication and supplier certification. Product failures in the shipbuilding industry have the potential to cause significant financial loss, imperil human lives and create environmental disaster. In response to the Exxon Valdez oil spill disaster in 1989, the US Congress passed the Oil Pollution Act of 1990 (OPA) which mandates that all oil tankers operating in US waters will be of "double hull" design by 2015 to minimize the potential for a disastrous oil spill. The OPA also mandated additional design changes in oil tankers and drilling platforms which has impelled the industry to adopt more stringent global standards for product, process and labor certification. As such, suppliers must navigate a more complex regulatory framework and comply with international standards as a qualifying condition for bidding on industry contracts (Nadvi and Waltrïng, 2004; Nadvi, 2008).

A benefit in the creation of certification standards is the extent to which the standards may simplify interactions and reduce transactions costs between lead firms and their suppliers. Standardization in component, product, and process specifications have contributed to a simplification of the bidding and award process between buyers and suppliers (Gereffi, Humphrey and Sturgeon, 2005). However, compliance with different product standards such the ones established by IMO (International Maritime Organization) and process quality standards (ISO 900I) has heightened the competitive challenge faced by suppliers in the shipbuilding industry. Technological competence is a necessary condition that firms need to develop in order to obtain worldwide certification. Also, the required amount of resources (money, time, production stoppages, and consulting costs) during the certification process can be an entry barrier, especially for small firms in emerging markets (Quadros, 2004).

According to the global value chain (GVC) literature, the diffusion of global standards, especially quality standards, has improved production processes, favoring supply chain upgrading by local suppliers (Quadros, 2004; Nadvi, 2008). However, these standards may not improve engineering ca- 
pabilities, and may actually weaken long-term relationships with global buyers (Quadros, 2004). Since shipbuilding is an engineering-to-order industry in which suppliers make products to a lead customer's specifications, we may assume that standards have limited influence in improving buyersupplier relationships when product specifications cannot be easily codified.

International standards may also affect inter-firm relationships and, consequently, governance in global value chains (Pietrobelli, 2007). Quadros (2004) and Navdi (2008) suggest two possible implications of global quality standards for chain governance. First, supplier certification may be seen by buyers as an indication of the capability of the supplier to take on further responsibilities. Conversely, certification may replace direct supplier monitoring and lead to more market based relationships in the chain. As a result, buyers may have little inclination to engage in ongoing initiatives with supplier to increase technological capabilities.

The complexity of transactions between firms and codifiability of information are also affected by international standards and may result in the development of new governance mechanisms in the supply chain. Gereffi, Humphrey, and Sturgeon (2005), suggest that when standards for codified specifications are widely known, suppliers and customers can be easily linked and unlinked from the value chain, resulting in a very fluid and flexible network structure. In the shipbuilding industry the product structure consists of interconnected systems, a hybrid governance type (called modular) may arise when suppliers have the ability to supply full packages/modules and turn-key services. However, competencies in supplying full packages/modules and turn-key services are unlikely to be found in local supplier networks in emerging markets. Turn-key services require technical expertise in critical areas and engineering competence to integrate parts from different suppliers according to customer specifications. This expertise and competence are characteristics of advanced technological capabilities (Figueiredo, 200I) and are more likely to be found in large global suppliers.

Horizontal cooperation between local suppliers may compensate for weaknesses in developing individual strategies to serve the industry. Economies of scale may exist in service delivery and technical assistance through collective institutions and joint actions involving producers at the clusterlevel and buyers and supply chain leaders (Pietrobelli, 2007; Schmitz, 1995). The cluster-level is often the appropriate one to promote cooperatives, to enable coordination and pooling of production, and the efficient delivery of technical assistance (Humphrey, 2003). In countries that have developed strong shipbuilding industry, South Korea for example, the creation of industrial clusters has benefitted from national investments in world class shipbuilding infrastructure, institutional capacity and specialized educational establishments, coupled with a relentless pursuit by shipbuilders and suppliers to continuously upgrade production efficiency (Sohn, Chang and Song, 20I0).

The aforementioned discussion underscores the key role that ongoing development of technological capabilities (TC) plays in developing local suppliers in emerging markets. The utilization of local suppliers by a large-scale industrial enterprise argues for an examination of different TC research perspectives. We present these perspectives in the next section.

\section{Research Streams on Technological Capabilities}

The first research perspective is focused on Technological Capabilities (TC) at the firm level. TC studies of firms in emerging countries assume that technology developments appear mainly at the firm level and are translated not only in new product/service development, equipment, installations, productive processes norms and procedures, but also in the development of the technical knowledge of the labor force (Lall, 1992, 2000; Bell and Pavitt, 1995; Figueiredo, 200 I).

To this end, an important facilitator of technological capability is organizational learning. Figueiredo (200I) considers the organizational learning process as a critical component of technological capability trajectories. Nonaka and Takeuchi (1995) argue that tacit knowledge from individuals needs to be converted into explicit knowledge and that firm learning processes depend on learning acquisition sources (external or internal) and firm knowledge conversion mechanisms. Conversion mechanisms are represented by the socialization process among firm employees and the codification processes of applying that learning into products, services, routines, procedures, manuals, etc (Wenger, 1998; Brown and Duguid, 2000).

The variety of knowledge acquisition modes - both internal and external - are important to technological capability development of firms in emerging markets (Figueiredo, 200I). Another important element for developing technological capabilities is the manner in which technology is transferred to firms in emerging countries. Various studies of firms in emerging markets argue that technology is considered not just an exogenous component available for anyone who wants to buy it (Gereffi, Humphrey and Sturgeon, 2005). Firms in those countries need capabilities to use, master, and adapt to local conditions the acquired technology in order to be successful. Suppliers in emerging markets may initially transfer technology from others but through development of an absorptive capacity (knowledge base and intensity efforts) they can move from imitation to creation of their own technology at some point in the future (Kishimoto, 2004). 
The second research stream for analyzing technological capabilities comes from the global value chain (GVC) literature. The GVC literature argues that the TC of local suppliers will have a major impact on the relationships between buyers and suppliers in a global value chain context. Depending on their level of technological capabilities, local suppliers may have the ability to rapidly upgrade their position in the value chain. Humphrey and Schmitz (2002) identify four types of upgrading. In process upgrading, suppliers transform inputs into outputs more efficiently by re-organizing the production system or by introducing superior technology. Product upgrading implies that suppliers gradually move into more sophisticated product lines. In functional upgrading suppliers acquire new functions (or abandon existing functions) to increase the level overall level of skill content. In inter-sectoral upgrading unaffiliated firms belonging to a local industrial cluster combine efforts to develop new productive activities that add value to the enterprise supply chain in a different but related industry ${ }^{4}$

Even with limited TC, local suppliers may have the capability to reconfigure their processes and products to upgrade their position in the value chain. It is arguably in the enterprise's best interest to develop local suppliers in order to mitigate the risks associated with purchases from distant suppliers. Problems like delivery delays and limited technical assistance at the enterprise site are compounded by the geographic and cultural distance between buyers and sellers ${ }^{5}$. While product and process upgrading may be encouraged by global buyers, the GVC literature has not found support for the assertion that global buyers actively engage in initiatives to facilitate local supplier upgrading. In fact, global buyers may perceive suppliers as a threat when they move into activities that may be closely related to the purchaser's core competencies (Quadros, 2004).

Capabilities in the supply base may also affect the ways enterprises coordinate or govern the linkages between value chain activities. Gereffi, Humphrey, and Sturgeon (2005) assert that different governance types arise in global value chains based on differences in transaction complexity, transaction codifiability, and supply-base capabilities. They argue that in the traditional spectrum of relationship arrangements characterized by arm's length (market-based) relationships at one extreme and hierarchical relationships at the other there are three hybrid forms of governance; captive, relational and modular ${ }^{6}$. Captive relationships are devel-

${ }^{4}$ Japanese motorcycle manufacturers for example have found success in exploiting small two stroke engine technologies in developing and pioneering applications in the personal watercraft industry. ${ }^{5}$ See Lunsford (2007) for issues related to problems that Boeing Aircraft had in developing a globally dispersed supplier base for the 787 Dreamliner project. oped with low competence suppliers, requiring intervention and control by the dominant partner in order to minimize the risk of supplier failure. Relational and modular buyersupplier relationships imply the existence higher capabilities in the supply-base, a lower need for oversight by the buyer and a concomitant increase in trust.

In relational value chains tacit knowledge is exchanged between buyers and sellers. Although spatial proximity plays a role in supporting relational value chain linkages, trust and reputation might well substitute for geographic proximity in spatially dispersed networks characterized by long-term relationships (Kumar, 1996; Gereffi, Humphrey, and Sturgeon, 2005). The exchange of complex information in this type of relationship is most often accomplished by frequent face-toface interaction between representatives of each side of the transaction and is governed by high levels of explicit coordination. This results in an increase in the bargaining power of the supplier and raises the cost associated with a buyer switching to a new supplier. Long-term relationships developed with trusted and competent suppliers are more likely to survive in the face of competitive threats from alternative supply sources (Dyer, 1996; Liker and Choi, 2004).

Organizations that belong to modular value chains make custom products to customer specifications, and may provide turn-key services in order to simplify the transaction. Turnkey service suppliers are very popular in capital equipment and heavy industries such as shipbuilding. Turn key suppliers do not necessarily produce products but act as aggregators of technologies provided by other vendors. The number of direct suppliers is reduced which reduces the transaction costs associated with dealing with a large number of separate suppliers. Turn key suppliers "take full responsibility for competencies surrounding process technology, use generic machinery that limits transaction-specific investments, and make capital outlays for components and materials on behalf of customers" (Gereffi, Humphrey and Sturgeon, 2005). Turn-key suppliers are able to develop their own technology, but primarily focus on the integration of technologies provided by other vendors? ${ }^{7}$.

An alternative view of technological capabilities comes from the perspective of firms located in industrial clusters. Industrial cluster theory argues that competitive advantage in certain industries is enhanced through the co-location of

${ }^{6}$ The reader should note that Internalization Theory in the International Business literature builds on this idea of arm's length (licensing agreements for example) and hierarchical relationships to explain the phenomenon of Foreign Direct Investment (see Dunning, 1988; Williamson, 1975).

${ }^{7}$ Observant readers may notice indirect reference to Williamson's (1975) work on Transaction Cost Economics. 
complementary firms. The creation of clusters encourages collaboration and cooperation between firms to develop more efficient combinations of physical and mental capital to enhance competitiveness (Porter, 1990, 2008; Schmitz, 1995; Niu, 2009; Arikan and Schilling, 20I I). Most notably, physical proximity increases the exchange of technical information between firms and can contribute to a general upgrading in technological capabilities. Investments made by government agencies, educational organizations, and private institutions, also contribute to an acceleration of innovative efforts by firms in the cluster (Wad, 2008). These cooperative relationships also encourage the initiation of joint technological efforts for product and process development. For example, firms in clusters in emerging markets may take part in cooperative certification programs, sharing consulting costs, developing certification protocols and educational initiatives and exchanging experiences. Humphrey and Schmitz (2002) bring the industrial cluster and GVC literature together by advocating that collective efficiency through interactions within the cluster will accelerate local supplier upgrading in global value chains.

A local cluster may expand the options available to a dominant buyer since different suppliers in the cluster may fill a large order through the combination of complementary functions. From the buyer's perspective, this allows tighter control over quality and delivery parameters because of the advantage of the geographic proximity of the supplier base. Suppliers, however, are not always perceived in the same way by a dominant buyer. Nassimbeni (2003), in an analysis of industrial clusters in the Italian eyewear industry, found discrimination between preferred and marginal suppliers based on technological and managerial factors. Implementation of initiatives to gain quality certification in the production process and improvements in the product design through the use of innovative materials were more pervasive in the preferred suppliers. In the absence of qualified local sourcing options, however, the enterprise is more likely to internalize those functions that might normally have been outsourced or may increase efforts to rationalize the supplier base by strengthening ties with and developing a more demanding relationship with a small select group of qualified suppliers. In this section we have discussed relationships between the technological capabilities of local suppliers and the supply chain decisions of new industrial enterprises in emerging countries. Local supplier TC will strongly influence the options available with respect to the enterprise's sourcing decisions. Furthermore, local suppliers in emerging markets may develop technological capabilities differently from suppliers in developed countries. In this context, the importance of technological dimensions on the enterprise sourcing decision has yet to be explored. Depending on those capabilities different types of relationships or governance may arise in the enterprise value chain. In addition, local supplier capabili- ties may affect the ability of upgrading in the enterprise value chain. Since governance and upgrading possibilities vary according to industry characteristics, analysis of the shipbuilding industry may help in better understanding of the role of value chains in emerging markets. In addition there is an ongoing debate concerning the impact of local industrial clusters on the development of the technological capabilities of its firms, and consequently on the enterprise sourcing decisions in emerging countries (Niu, 2009; Mcdermott and Corredoira, 2010).

In the next section we derive propositions about the role of technological capabilities for local firms' prospects of supplying to a dominant buyer in an emerging market. Our analysis focuses on the micro level perspective in which the technology developments in emerging markets appears mainly at the firm level (Lall, 1992, 2000; Bell and Pavitt, 1995; Figueiredo, 200I).

\section{Propositions}

With regard to the improvement of technological capabilities in firms from emerging markets we find a different development trajectory from that of firms based in developed countries. Emerging market suppliers expand technical knowledge by searching for, operating and mastering technology developed by others rather than by developing their own technology through internal research and development initiatives. In this regard, TC trajectories will normally follow a multistage sequence: a) developing operating and production capabilities b) enhancement of design, engineering and associated management capabilities and c) eventual development of internal R\&D capabilities (Bell, 2007).

A number of studies have examined the development of firm TC in emerging countries (Lall, 2000; Bell and Pavitt, 1995; Figueiredo 200I). Technology capabilities are discussed into two dimensions: technology functions and technology levels (Bell, 2007). Technology function is concerned with different kinds of firm core capabilities that need to be internalized in order to use, master, and modify a new technology (Lall, 2000; Bell and Pavitt, 1995).

Technology levels refer to the extent to which the firm is capable of developing and exploiting either internally or externally generated technological innovations. Lall (2000) and Bell and Pavitt (1995) present different TC levels such as: basic or simple routine capabilities (experience based); intermediate or adaptive capabilities (search based); advanced or innovative capabilities (research based). TC levels indicate how sophisticated the firm technology is. Sophistication in this case could be represented by innovative capabilities in products, processes/activities, equipment, and especially the technological knowledge and innovative abilities of the labor force. 
The shipbuilding industry requires a moderate level of technological sophistication in design and production (Sohn, Chang and Song, 2010; Birkler et al., 2004; Cho and Porter, 1986), and consequently, a high technological capability level is expected for suppliers, especially with respect to the acquisition of external certifications. To reach that level a supplier might have made significant investments in transferring and mastering technology from others with the eventual objective of developing internal capabilities in technology innovation. Most likely, global suppliers or local suppliers with a global reach are capable of delivering the highest value added products and services to buyers. Those suppliers have made the large investments in technological capability that are needed to attain global competitiveness and must actively seek out new markets to amortize these investments over a larger customer base.

The insertion of local suppliers at the first tier of the enterprise supply chain is also limited by industry specific qualification factors. For example, as discussed in an earlier section, parts, components and subassemblies supplied to shipyards must comply with technical requirements demanded by international certification organizations such as the International Maritime Organization (IMO) ${ }^{8}$. As such, dominant firms in the industry require compliance with global process and labor standards from well established first tier suppliers. Suppliers with a global reach will have developed internal competencies to comply with the standards and certifications needed for product performance, process design and protocols, labor quality and environmental sustainability, and will have a working relationship with certification organizations. These competencies signal to buyers that the supplier has made the investments needed to comply with the regulatory (certification) environment and will create an entry barrier that local firms in emerging markets may find difficult to surmount.Also,Araújo, Dalcol and Longo (20I I) implicitly suggest that firms in the Brazilian shipbuilding sector with international penetration are more technologically advanced. Those authors recommend that firms in that sector revise their organizational culture "in order to get a technological advancement able to contribute for competitiveness, at international level, and reduce their dependence on domestic orders". Indeed, buyers in this industry will develop an inventory of qualified suppliers that can be used to access production services and materials. Following this discussion, we propose:

\footnotetext{
${ }^{8}$ The global shipbuilding industry is very similar to the global aviation industry with respect to the extent of tight external controls and the need for external certification of the production process.
}

Proposition I $a$-The proportion of local suppliers (in an emerging market) with international penetration at the first tier of the enterprise supply chain will be significantly higher than at lower tiers.

In contrast to the level of or sophistication of technological capabilities, TC scope is concerned with the extent or variety of possible technological functions and is another dimension of the technology capability matrix (Figueiredo, 200I). Considering that TC functions are aligned along the value chain then, in addition to production, pre-production (planning) and post-production (exploring markets) phases are also important from a technology perspective. Sato and Fujita (2009) in their development of a technology capabilities assessment tool emphasize the importance of an evaluation of the breadth of the firm's activities along the value chain. They emphasize the role of branding and marketing activities beyond the investment and production functions and argue for the importance of linkages with stakeholders to facilitate the efficient transfer of knowledge. Lall (1992) defines linkages as the skills needed to transmit information and technology from and to other organizations (suppliers, buyers, universities, subcontractors, etc.) within the context of what can be termed a National Innovation System.An important facilitator is the role of the public sector in emerging countries in developing linkages with local firms through subcontracting and extension services. Lall's research on the impacts of local content policies in emerging markets like Taiwan required a significant transfer of technology, increased backward linkages and upgrading of competitive capabilities for the industry as a whole (Lall, 2000).Araújo, Dalcol and Longo (20II) found that Brazilian suppliers at the shipbuilding sector develop partnerships with other organizations for innovation purpose and construction of abilities. We speculate that local suppliers in emerging countries that have developed linkage capabilities (in addition to production capabilities) and can benefit more from opportunities such as subcontracting, government funded research initiatives, and local content policy which are common practices in the shipbuilding industry in countries like Brazil. Thus, we argue:

Proposition Ib-The better are the local supplier linkages with buying firms, other suppliers and organization of the National Innovation System (Universities, research centers, etc.) the higher the supplier chances of joining the enterprise supply chain (as direct or indirect member).

Transaction cost theory can also provide an explanation of the different possibilities for participation of local supplier in the enterprise supply chain. According to Balbinot (2006), transaction costs may be seen as incentives as well as disadvantages to buyer-supplier alliances. Initial stages of the relationship typically involves high transaction costs in terms of

ISSN: 07 I8-2724. (http://www.jotmi.org)

Journal of Technology Management \& Innovation (C) Universidad Alberto Hurtado, Facultad de Economía y Negocios. 
contract negotiation and due diligence on the part of both parties to the transaction. Although a critical part of the overall process, this stage may be considered a disadvantage, especially when the partnership is new and the suppliers have little experience in terms of developing a product/service offering that meets the needs of the buyer.According to Kogut (1988) a firm may choose to produce a component even though its production costs are higher than the ones for manufacturing the component outside. When transaction costs are high for monitoring local or global suppliers the new enterprise may decide to produce parts internally. From this can infer that initially new industrial enterprises will produce as many inputs as possible internally before looking to involve external suppliers in the supply chain. Of course those parts are related to daily shipyard functions rather than high-technology components. Since there are local government loans for mitigating high production costs in emerging countries, we can argue that:

Proposition Ic - New industrial enterprises will produce as many low-technology parts internally as possible at the beginning of its production.

The reasoning above is especially relevant for suppliers of services since it is generally more difficult to enforce service supply contracts than contracts for tangible products. For activities that may be beyond the expertise of the buyer, the firm tends to rely on contract negotiation for one-time purchase and alliances for regular purchases. However, service contract negotiation would be more complex than product contract negotiation due to a more subjective evaluation of service quality metrics in comparison to more objective measures of product quality.Also, in contrast to parts suppliers, service oriented activities will normally require a physical presence at the client site. Thus, we propose:

Proposition Id -The insertion of a local service supplier (as direct or indirect supplier) is more likely in the enterprise production supply chain (industrial production phase) than the insertion of a local product supplier.

Local suppliers (direct or indirect) also have the ability of upgrading their participation in the enterprise supply chain. They may have advantages in some types of upgrading, but may find barriers in other types (Humphrey and Schmitz, 2002; McDermott and Corredoira, 2010). Upgrading in industrial sectors may differ in terms of technological complexity and in the modes and sources of innovation (Pietrobelli and Rabellotti, 2004). Local supplier upgrading differs by industrial sectors depending on the intensity of technological externalities and cooperation among local actors.

Giuliani, Pietrobelli and Rabelloti (2005), in a study of upgrading in Latin American industrial clusters, found several examples of process (and to a lower extent product) upgrading in the case of suppliers to assemblers of complex products, but examples of functional upgrading was seen in only a few cases. The manufacturing of complex, high cost, engineering-intensive products (automobile, aircraft) where the process of technical change is constrained by the needs of product design parameters. Change tended to be slow and incremental and was often a function of supplier abilities to develop modular solutions to buyer's requirements. In this case, the local supplier network was anchored to one large assembler, which operates as a leading firm with a crucial role to foster (or hinder) firms' upgrading through technology and skill transfers. Similarly, Quadros (2004), found that dominant buyer firms in the value chain initiated few efforts to help local supplier upgrading in the Brazilian automotive sector. Unfortunately, a dominant buyer(s) may not always have the inclination to assist local suppliers in any type of upgrading other than to reduce costs.

Once local firms receive purchase orders from a dominant buyer(s), we speculate that in face of competitive pressure posed by global suppliers these firms will focus on whatever initiatives are needed to retain orders rather than increasing the value added of the product or service mix. Thus, local supplier efforts will most likely be focused on retaining orders of the same items by exploiting scale economies to lower costs and increase quality. Thus:

Proposition $2 a-$ local suppliers connected to the enterprise supply chain are more likely to engage in process upgrading than other forms of upgrading.

Studies in the GVC literature that examines upgrading in producer-driven industries can be used to analyze the extent of upgrading in the shipbuilding industry. Quadro's (2004) work analyzing the Brazilian automotive industry found that the diffusion of global standards led to improvements in local suppliers' production processes but not in further development of engineering capabilities. Since those capabilities are critical for designing better quality products or taking on higher value added functions in the supply chain, we assume that there are limited opportunities for product and functional upgrading in producer-driven industries. In functional upgrading local suppliers perform higher value added activities for global buyers, but this type of upgrading requires stronger relationships with those buyers. Nadvi (2008), in fact, found that the pressure to upgrade quality standards weakened the relationship between local suppliers and global buyers. Consequently, we can speculate that:

Proposition $2 b$ - Functional upgrading will be least likely type of upgrading for local suppliers connected to the enterprise supply chain. 
Firms and clusters often do not operate only in one supply chain but may operate simultaneously in supply chains in other industries. Skills and innovations developed in one industry may then be transferred to efforts to win orders in these other supply chains (Humphrey and Schmitz, 2002). Achieving economies of scale and competencies required to win business from a new industrial enterprise is likely to be less difficult for suppliers that are already involved with other supply chains than for those suppliers that are just developing capabilities. This inter-sectoral upgrading often happens in emerging economies as local firms discover opportunities to transfer learning in one industry to a different but related industry. For instance, horizontal movements into new industrial sectors have been central to countries such as Taiwan which developed an ability to exploit advantages in skill intensive sectors such as the production of computer monitors to develop a globally competitive television industry (Humphrey and Schmitz, 2002; Kishimoto, 2004). The GVC literature also argues for the importance of reputation as a critical factor in developing relationships with competent local suppliers (Gereffi, Humphrey and Sturgeon, 2005). Hence, it follows that local firms already supplying buyers in other supply chains will likely have a better overall reputation than other suppliers that do not have this experience. Buyers in the new enterprise are likely to assess the risks of engagement with the local supplier on the basis of the extent to which this firm has experience with buyers in other industries. Consequently, the limited technological capabilities of local suppliers in the industry sector of a new industrial enterprise will favor inter-sectoral upgrading. Thus, we propose that:

Proposition $2 c$-The more limited the technological capabilities of local suppliers in the industry sector of the new enterprise then the greater the likelihood that there were be higher levels of intersectoral upgrading by suppliers from other industries.

\section{Conclusion}

As economic activity shifts away from developed economies towards emerging markets, the ability of firms in these markets to stand on their own as global competitors is of paramount importance. The major contribution of this paper lies in its discussion of the concept of the development of technological capabilities of firms in these emerging markets and the extent to which they can win orders from large industrial enterprises competing in global industries. Building on research on firm technological capabilities in emerging markets, global value chains and industrial clusters we explore the participation of local suppliers in emerging markets in the supply chain of a dominant buyer. Using Brazilian shipyards as our focus, we derive prepositions about the role of technological capabilities on local supplier participation in the shipbuilding value chain.
In addition to knowledge from previous studies on global value chains, we find support from traditional theories such as transaction cost economics in understanding global and local sourcing decisions taken by a new enterprise in an emerging market. We intend to validate and improve the propositions presented in this paper through a survey of suppliers in the Brazilian shipbuilding industry. Hopefully, we can test them in the same study and provide a better understanding of the importance of technological capabilities for firms in emerging countries.

\section{References}

ANDRITSOS, F. and Perez-Prat, J. (2000). The Automation and Integration of Production Processes in Shipbuilding. State-of-the-Art report, Joint Research Centre. European Commission, Europe.

AMORIM, F. Araujo, E.; Serra. T. and Rosental. R. (1995). A Global Evaluation of the Brazilian Shipbuilding Industry. Transactions on the Built Environment. WIT Press, II. Ashurst, Southampton, England.

ARAÚJO, F. O.; Dalcol, P. R.T. and Longo,W. P. (201I).A Diagnosis of Brazilian Shipbuilding Industry on the Basis of Methodology for an Analysis of Sectorial Systems of Innovation. Journal of Technology Management \& Innovation, Volume 6, Issue 4, pp. |5|-|7|.

ARIKAN, A. and Schilling, M. (20I I). Structure and Governance in Industrial Districts: Implications for Competitive Advantage. Journal of Management Studies, 48(4), pp. 772- 803.

BALBINOT, Z. (2006). Building technological capabilities in Brazilian Firms through alliances. Ph.D. Thesis, University of Montreal, Canada.

BELL, M. (2007). Technological Learning and the Development of Production and Innovative Capacities in the Industry and Infrastructure Sectors of the Least Developed Countries: What Roles for ODA? UNCTAD The Least Developed Countries Report Background Paper.

BELL, M. and Pavitt, K. (1995). The Development of Technological Capabilities. in Irfan ul Haque, ed., Trade, Technology, and International Competitiveness. EDI Development Studies. The World Bank, Washington, DC.

BERNARDES, R. and Oliveira, L. (2003). Building up complex productive systems in developing countries: the Embraer experience. in Cassiolato, J., Lastres, H., and Maciel, M., Systems of Innovation and Development: Evidence from Brazil. Edward Elgar, Cheltenham, UK. 
BIRKLER, J.; Rushworth, D.; Chiesa, J.; Pung, H.; Arena M. and Shank, J.. (2004). Differences Between Military and Commercial Shipbuilding: Implications for the United Kingdom's Ministry of Defense. Rand Europe, Rand, Santa Monica

BLOUNT, J. (2009). Brazil Sees Subsalt Reviving Shipbuilding. Platts Oilgram News,Vol. 87 (I80), September I4, p. 7.

BROWN, J.S. and Duguid, P. (2000). The Social Life of Information, Harvard Business School Press, Cambridge, MA.

CHO, D. S. and Porter, M. (1986). Changing Global Industry Leadership: The Case of Shipbuilding. in Competition in Global Industries, M. Porter ed. Harvard business School Press, pp. 539 -567, Boston.

DUNNING, J. (1988). Explaining International Production. Unwin Hyman, London.

DYER, J. (1996). How Chrysler Created an American Keiretsu. Harvard Business Review, July-August, pp. 2-II.

FAIRPLAY.(2009). Brazil's Shipbuidling Hopes. Fairplay October 15. www.fairplay.co.uk/2009oct /5newbuilds.pdf [acessed September 15, 2010].

FIGUEIREDO, P. N. (200I). Technological learning and competitive performance. Edward Elgar, Cheltenham.

FIGUEIREDO, P. (2007). Industrial Policy Changes and FirmLevel Technological Capability Development: Evidence from Northern Brazil.World Development, 36(I), pp. 55-88.

GEREFFI, G.; Humphrey, J. and Sturgeon, T. (2005). The governance of global value chains, Review of International Political Economy, 12(I), pp. 78-104.

GIULIANI, E.; Pietrobelli, C. and Rabellotti, R. (2005). Upgrading in global value chains: Lessons from Latin America clusters. World Development 33 (4), pp. 549-573.

HELLSTRÖM, M. (2005). Business Concepts Based on Modularity A Clinical Inquiry into the Business of Delivering Projects, Dissertation at Åbo Akademi University, Åbo Akademi University Press.

HUMPHREY, J. and Schmitz, H. (2002). How does insertion in global value chains affect upgrading in industrial clusters? Regional Studies, 36 (9), pp. 1017-1027.

HUMPHREY, J. (2003). Globalisation and Supply Chain Networks: The Auto Industry in Brazil and India'. Global Network, 3(2), pp. |2|-4|.
JIN, B., (2004). Achieving an optimal global versus domestic sourcing balance under demand uncertainty. International Journal of Operations \& Production Management, 24(I2), pp. I292-I 305.

KIM, L. (2000). The Dynamics of Technological learning in Industrialization. The United Nations University, Discussion Paper Series, pp. I-35.

KIM, G. C. and Takeda, E. (1996). The JIT Philosophy is the Culture in Japan. Production and Inventory Management Journal, 37(I), pp. 47-5I.

KISHIMOTO, C. (2004). Clustering and Upgrading in Global Value Chains: the Taiwanese Personal Computer Industry. in Local enterprises in the global economy: issues of governance and upgrading. Schmitz, H, ed., Edward Elgar Publishing Limited, Cheltenham, UK.

KOENIG, P. (2002). Technical and economic breakdown of value added in shipbuilding. Journal of Ship Production, 18(I). Koenig, P.; Narita, H. and Baba, K. (2002). Lean production in the Japanese shipbuilding industry. Journal of Ship Production, $18(3)$.

KOGUT, B. (1988). Joint Ventures: Theoretical and empirical perspectives, Strategic Management Journal, 9, pp. 319-332.

KOGUT, B. and U. Zander. (2003). Knowledge of the Firm and the Evolutionary Theory of the Multinational Corporation. Journal of International Business Studies, 34, pp. 516 $-529$.

KOTABE, M. (1992). Global Sourcing Strategy. Quorum, New York.

KUMAR, N. (1996). The Power of Trust in ManufacturerRetailer Relationships. Harvard Business Review, 74(6), pp. 92-106.

LALL, S. (1992). Technological capabilities and industrialization. Research Policy, 20(2), pp. I65-I86.

LALL, S. (2000). National strategies for technology adoption in the industrial sector: Lessons of recent experience in the developing regions. Human Development Report 2001: Harnessing Technology for Human Development, pp. I-82.

LIKER, J.K. and Choi,T.Y. (2004). Building Deeper Supplier Relationships. Harvard Business Review, December.

LUNSFORD, J. (2007). Jet Blues. The Wall Street Journal, December 7,AI. 
MARKHAM, S. and McCart, D. (1995). The road to successful implementation of just-in-time systems. Production and Inventory Management Journal,Vol. 36, 3rd quarter, pp. 67-70.

MCDERMOTT, G. and Corredoira, R. (2010). Network Composition, collaborative ties, and upgrading in emergingmarket firms: Lessons from the Argentine Auto parts Sector. Journal of International Business Studies, 4I, pp. 308 - 328.

NADVI, K. (2008). Global standards, global governance and the organization of global value chains. Journal of Economic Geography, 8, pp.I-2I.

NADVI, K. and Waltrïng, F. (2004). Making sense of Global Standards. In Local enterprises in the global economy: issues of governance and upgrading. Schmitz, H. ed., Edward Elgar Publishing Limited, Cheltenham, UK.

NASSIMBENI, G. (2003). Local manufacturing systems and global economy: are they compatible? The case of the Italian eyewear district. Journal of Operations Management, 2I, PP. $|5|-|7|$.

NIU, K. (2009). The Involvement of Firms in Industrial Clusters: A Conceptual Analysis. International Journal of Management, 26(3), pp. 445-455.

NONAKA, I. and Takeuchi, H. (1995). The knowledge-creating company: how Japanese companies create the dynamics of innovation. Oxford University Press, New York.

PASIN, J. (2002). Indústria Naval do Brasil: Panorama, Desafios e Perspectivas. Revista do BNDES, 9(18), pp. |2|-| 48.

PIETROBELLI, C. (2007). Global Value Chains and Clusters in LDCs:What Prospects for Upgrading and Technological Capabilities, UNCTAD The Least Developed Countries Report 2007 Background Paper.

PIETROBELLI, C. and Rabellotti R. (2004). Upgrading in Clusters and Value Chains in Latin America:The Role of Policies. Sustainable Development Department Best practices series, MSM-I 24, January.

PORTER, M.E. (1990). The Competitive Advantage of Nations. MacMillan, London.

PORTER, M.E. (2008). Location, Competition and Economic Development: Local Clusters in a Global Economy. Economic Development Quarterly, I4(I), pp. 15-34.

QUADROS, R. (2004). Global quality standards and technological upgrading in the Brazilian Auto components industry. in Local enterprises in the global economy: issues of govern- ance and upgrading. Schmitz, H, ed., Edward Elgar Publishing Limited, Cheltenham, UK.

SATO, Y. and Fujita, M. (2009). Capability matrix: a Framework for Analyzing Capabilities in Value Chains. Institute of Developing Economies: JETRO. IDE Discussion paper \#219.

SCHMITZ, H. (1995). Collective efficiency: Growth path for small scale industry. Journal of Development Studies, 3 I (4), Pp. 529-566.

SOHN, E.. Chang, S. and Song, J. (2010). Technological Catching-up and Latecomer Strategy: A Case Study of the Asian Shipbuilding Industry. Seoul Journal of Busines, I5(2).

STURGEON, T.; Biesebroeck, J. V. and Gereffi. G. (2008). Value Chains, Networks and Clusters: Reframing the Global Automotive Industry. Journal of Economic Geography, 8, pp. 297-321.

WAD, P. (2008). The Development of Automotive Parts Suppliers in Korea and Malaysia:A Global Value Chain Perspective.Asia Pacific Business Review, I4(I), pp. 47-64.

WENGER, E. (1998). Communities of Practice: learning meaning and identity. Cambridge University Press, Cambridge.

WILLIAMSON, O. (1975). Markets and Hierarchies:Analysis and Antitrust Implications. The Free Press, New York.

WOMACK, J. and Jones, D. (1996). Beyond Toyota: How to Root Out Waste and Pursue Perfection. Harvard Business Review, September-October, pp. I 40-I58.

WORLDYARDS, (2009). Market Comment, 18 November. Brazilian Shipbuilding in Rejuvenation? www.worldyards. com [accessed December 9, 2010]. 
J.Technol. Manag. Innov. 2012,Volume 7, Issue 2

ISSN: 07I8-2724. (http://www.jotmi.org)

Journal of Technology Management \& Innovation @ Universidad Alberto Hurtado, Facultad de Economía y Negocios. 